Article

\title{
Effect of Institutional Quality and Wealth from Oil Revenue on Economic Growth in Oil-Exporting Developing Countries
}

\author{
Adewale Samuel Hassan ${ }^{1}$ (D), Daniel Francois Meyer ${ }^{1}$ and Sebastian $\operatorname{Kot}^{1,2, *(\mathbb{D})}$ \\ 1 Faculty of Economic and Management Sciences, TRADE Research Entity, North-West University, \\ Vaal Triangle Campus, P.O. Box 1174, Vanderbijlpark 1900, South Africa \\ 2 The Management Faculty, Czestochowa University of Technology, Armii Krajowej 19B, 42-200 Czestochowa, \\ Poland \\ * Correspondence: sebacat@pcz.zim.pcz.pl; Tel.: +48-34-3250-300
}

Received: 25 May 2019; Accepted: 26 June 2019; Published: 2 July 2019

\begin{abstract}
This article investigates the role of institutional quality in the oil wealth-economic growth nexus for 35 oil-exporting developing countries between 1984 and 2016. To achieve this objective, an empirical model was employed with linear interaction between oil wealth and institutional quality, and estimated by means of panel autoregressive distributed lag (ARDL) with a dynamic fixed effect estimator. From the results, a contingent effect of oil wealth on economic growth, both in the long run and in the short run, was established. Specifically, institutional quality was found to mitigate the negative effect of oil wealth on economic growth in the long run, while in the short run, institutional quality was found to enhance the positive effect of oil wealth on economic growth. Furthermore, the results provide the threshold levels of institutional quality, beyond which oil wealth enhances economic growth, both in the long run and in the short run, for the sampled countries. These results suggest that in order for oil-exporting developing countries to benefit from an increase in oil wealth, they must adopt appropriate policy measures to improve their levels of institutional quality and embed their entire oil wealth-generating mechanism in a sound institutional framework. Also of importance is that governments must ensure sustainable development through the benefits of wealth from oil.
\end{abstract}

Keywords: panel ARDL; resource curse; threshold

\section{Introduction}

Analyses of the impact of natural resources on economic growth have been crucial to building an analytical framework for sustainable development in resource-rich developing countries. One of the most important findings in this process is that abundant natural resources might either enhance an economy's growth rate or slow it down, depending on the manner of management of revenue accruing from the resources [1-4]. Studies have also shown that resource-rich economies have tended to record slower growth than relatively resource-poor countries [5-12]. This anomaly has led to a debate in the literature, giving rise to the natural resource curse hypothesis, which relates abundant resources to lower growth [1] and to armed civil conflict [13]. One such natural resource is crude oil, which for decades has remained the mainstay of several oil-exporting developing economies, with revenue accruing from it accounting for a substantial share of their gross domestic product (GDP).

Indeed, there are several cases that seem to validate the resource curse hypothesis. For example, while countries with fewer natural resources such as the Asian tigers have been recording high economic growth, oil-rich economies such as Algeria, Angola, Iran, Nigeria, and Venezuela have 
recorded substantial declines in their per capita income during recent decades. Venezuela used to be one of the richest countries in the 19th century; however, for years now, the economy has dropped steeply into a cycle of economic crises, despite possessing one of the largest oil reserves in the world: the annual inflation rate climbed to as high as $83,000 \%$ in July, 2018. In addition, Nigeria has earned over US $\$ 600$ billion in oil revenues since the 1970s, but according to AfDB [14], about $80 \%$ of Nigerians still live on less than $\$ 2$ a day as at 2018. On the other hand, some resource-rich economies have defied the natural resource curse hypothesis. For example, Norway, despite being one of the poorest economies in Europe in the early 20th century, has now emerged as one of the richest European economies by harnessing its natural resources such as timber, crude oil, and natural gas [15,16]. Moreover, Botswana has been one of the fastest growing economies in the world since 1965, despite relying on diamonds for at least $40 \%$ of its GDP [5]. These examples corroborate some recent findings that challenge the existing resource curse literature. These studies opine that abundant natural resources strongly enhance economic growth and welfare [17-22].

In the literature, studies have explained the resource curse by the rent-seeking, Dutch disease, and institutional quality models [7]; Sachs and Warner, [5]; Gylfason and Zoega, [9]). Out of these three models, the role of institutional quality has been unanimously accentuated by the two opposing proponents of the rent-seeking and Dutch disease models [23,24]. For example, the impressive record of Botswana has been ascribed to good institutions by Acemoglu, Johnson, and Robinson [25]; Norway is also adjudged as one of the least corrupt countries in the world [15], while several oil-rich developing countries with low growth have been found to be characterized by poor institutional quality [5]. Corroborating these examples, Sarmidi et al. [26] suggest that natural resource endowment can only enhance economic growth if the level of institutional quality in the country is beyond a certain minimum level. Furthermore, Mehlum et al. [3] posit that countries with abundant natural resources, coupled with high levels of institutional quality record higher levels of human welfare and economic growth.

The aim of this study is to explore the role of institutional quality in the relationship between oil wealth and economic growth in oil-exporting developing countries. While the literature is replete with studies into the impact of natural resources on economic growth, vis-à-vis the resource curse hypothesis, the role of institutions in this relationship has not received adequate attention, especially as it concerns crude oil. Furthermore, previous studies on the subject as conducted by Olomola [27] for oil-exporting African countries, as well as Olayungbo and Adediran [28] for Nigeria, employed very limited definitions of institutions in their analyses. While the former study employed democracy and institutionalized constraints to capture institutions, the latter employed only corruption in their study [29,30]. This study will employ institutional variables that capture most aspects of domestic institutional structure. The said variables include bureaucratic quality, corruption, democratic accountability, government stability, and law and order. Furthermore, this study will make a contribution to the stream of research on the subject by shedding light on the potential optimal threshold level of institutional quality in the oil wealth-economic growth nexus for oil-exporting developing countries. This has not been considered by any known previous study on the subject. The rest of the paper is organized as follows. Section 2 contains a review of the literature, while the methodology for the study is articulated in Section 3. Model estimation and analysis of results are presented in Section 4, while Section 5 concludes the study.

\section{Literature Review}

The literature on the subject comprises those studies into the effect of natural resources on economic growth on the one hand, as well as those into the role of institutions in the natural resource-economic growth (and oil wealth-economic growth) nexus on the other hand. By investigating the relationship between natural resource abundance and economic growth between 1971 and 1989, Sachs and Warner [5] found that economies with a high natural resource exports/GDP ratio in 1971 have tended to experience slow growth during the remaining years under study. This result remains valid even after controlling for other important variables such as initial per capita income, government efficiency, investment, and trade policy. Also, in a subsequent study, Sachs and Warner [1] considered the nexus between 
natural resource abundance and the Dutch disease in the case of 95 developing countries for the period 1970-1990. The results from their study reveal that resource-rich economies recorded lower growth rates, which resulted directly from negative impacts of corruption, rent-seeking, and poor governance, as well as indirectly from reduction in investment demand. Similarly, in a study of the oil wealth-economic growth nexus in 47 oil-exporting countries and 13 non-oil exporting countries from 1970 to 2000, Olomola [27] employed the system generalized method of moments (GMM) estimation technique and established that that there is evidence of the resource curse in oil-exporting countries. He concluded that in the oil-exporting countries, oil revenue has not enhanced economic growth.

In an earlier study, Gylfason [7] investigated the impact of natural resources on long-term growth in 65 resource-rich economies between 1970 and 2008. From his analysis, he reported that only 4, out of the 65 , countries were able to record more than $4 \%$ growth per annum in per capita income on the average. Furthermore, he ascribed the failure of the remaining 61 countries, to achieve a similar result, to absolute dependence on natural resources and inadequate attention to other economic resources. Moreover, in an investigation into why most resource-rich countries underperform, Papyrakis and Gerlagh [31] employed cross-country regressions to examine the direct and indirect effects of natural resource abundance on economic growth from 1975 to 1996 . Their results show that abundant natural resources enhance growth in the absence of the transmission channels, which include corruption, trade openness, investment, and terms of trade. They also claimed that on the other hand, abundant natural resources strongly affect growth negatively if the transmission channels are taken into consideration. They concluded that the most influential of all the channels is investment.

Similarly, by employing an equilibrium model, Torvik [32] elucidated why resource-rich countries may suffer deterioration in income and welfare through rent seeking. The model shows that abundant natural resources lead to more entrepreneurs engaging in rent seeking and a lower numbers of firms operating productively, with the consequence being that the resulting reduction in income is greater than the increase in income from the natural resource. He thus concluded that abundant natural resources lead to lower welfare. Contrariwise, Alexeev and Conrad [33] showed that as opposed to several claims regarding the negative effects of large resource endowment on growth, the impact of large endowments of oil and other resources has been largely positive on long-term growth. In the same vein, the veracity of the resource curse hypothesis was investigated by Victor, Vladimir, and Alexander [34]. Their analysis revealed that resource-rich countries enjoy a greater inflow of foreign direct investment, larger foreign reserves, lower domestic fuel prices, higher GDP energy intensity, lower budget deficit, and lower inflation, which are all ancillaries to long-term growth. However, they also found that these economies are plagued with higher real exchange rates, retarded human capital accumulation, and worse institutional quality.

In another study, Mehlum, Moene, and Torvik [3] attempted to explain why resource-rich economies have diverging experiences regarding growth. By investigating 87 such countries, they established that the quality of institutions is responsible for these varying experiences, in which case more natural resources depress growth in the face of grabber-friendly institutions, while the given resources enhance growth when institutions are producer-friendly. They thus concluded that institutions are a major determinant of the resource curse. Furthermore, investigating why the growth rate is slower in resource-abundant countries than in resource-poor countries, Sarmidi, Law, and Jafari [26] employed panel data for 90 countries between 1984 and 2005. Using the Hansen [35,36] threshold estimation method, they reported that natural resources can enhance growth only after a certain threshold of institutional quality has been reached. They also concluded that countries with poor institutional quality are associated with a heavy dependence on natural resources, while countries with rich institutional quality are usually less dependent on such resources.

In addition, Gylfason [2] examined the link between natural resources and economic growth for resource-rich countries of the world since 1965. In his cross-country analysis, he showed that in comparison to countries with less resources, countries that are heavily dependent on natural resources tend to record less trade and foreign investment, less domestic investment, more corruption, 
less education, less equality, less political liberty, and less financial depth. However, following his comparison of the experience of the OPEC member countries with that of Norway, he concluded that efficient and far-sighted management of natural resources is an obvious possibility.

Moreover, Tsui [37] studied the impact of oil wealth on democracy using data for 65 top oil-producing countries and instrumental variable regression. He found that oil wealth exerts negative impacts on democracy. He further asserted that the impact is heavier for economies with higher oil deposits and lower exploration and extraction costs. In his submission, the impact becomes less precise when oil abundance is measured by oil discovery per capita, which suggests that politicians are more likely to be concerned about the level, rather than the per capita value, of oil wealth. This finding is corroborated by a similar study from Collier and Hoffler [13] who declared that abundance of natural resources substantially enhances the possibilities of civil conflict in the country and also that such resources exert a strong and nonlinear impact on conflict.

Similarly, in an analysis of the relationship between natural resources, human capital, and economic development in Nigeria, Godwin and Chuka [38] reported that natural resource abundance crowds out human capital and depresses growth, through its adverse effects on institutions. Furthermore, from carrying out both theoretical and empirical analyses of the channels of transmission between natural resources and growth, Leite and Weidmann [39] claimed that abundance of natural resources engenders rent-seeking behaviour, which in turn determines the country's corruption level. They also averred that the corruption level in an economy is determined by government policies, concentration of bureaucratic power, and natural resource abundance. Meanwhile, a contrary result was reported by Smith [40] in a study on the effect of oil wealth on regime survival in developing countries. By employing cross-sectional time-series data from 107 countries between 1960 and 1999, the results of the logistic regressions in the study showed that oil wealth strongly enhances regime durability, with a lower likelihood of civil war and anti-state protests. He also avowed that neither the boom nor the bust periods in the oil market affect regime durability in those countries with oil as their economies' mainstay.

In an evaluation of the resource curse hypothesis in Venezuala, Ross [8] averred that the prevalence of the resource curse in the economy could be attributed to bad democracy and weak institutions. He further opined that oil wealth makes a society more corrupt, authoritarian, and violent. Also, in an empirical analysis of the resource curse in Nigeria, Akinwale [41] revealed that the resource curse in Nigeria is reinforced by corruption, weak institutions, and the Dutch disease, while there is no strong link between crude oil price volatility and the resource curse in the economy. He concluded that efforts geared towards eliminating this curse from this economy would remain futile as long as corruption and weak institutions remain dominant in the country. This result is supported by the findings of a similar study on Nigeria by Ologunla, Kareem, and Raheem [42], which indicated that the relationship between institutions and the resource curse in Nigeria is negative. Finally, in a study on the effect of oil revenue and institutional quality on growth in Nigeria, Olayungbo and Adediran [28] claimed that institutional quality enhances growth in the short run, while it depresses the latter in the long run. They also reported that oil revenue improves growth in the short run, but retards it in the long run. Their conclusion was that institutional quality is key in elucidating the oil revenue-economic growth nexus in the country.

\section{Method}

\subsection{Econometric Model}

To reiterate, the focus of this study is an examination of the role of institutional quality in the oil wealth-economic growth nexus in oil-exporting developing countries. To this end, the following empirical equation is specified:

$$
L G D P C_{i t}=\alpha_{i}+\beta_{0} O L W_{i t}+\beta_{1}\left(O L W_{i t} * I N S Q_{i t}\right)+\theta I N S Q_{i t}+\gamma L Z_{i t}+\varepsilon_{i t} .
$$


In the model, $L G D P C_{i t}$ is $\log$ of GDP per capita; $O L W_{i t}$ is oil wealth; $I N S Q_{i t}$ is institutional quality; $L Z_{i t}$ is a vector of control variables in $\log$ form; $\alpha_{i}$ is an unobserved country specific effect; and $\varepsilon_{i t}$ is the error term. Equation (1) indicates that the responsiveness of economic growth to oil wealth is contingent upon an indicator of institutional quality. It thus allows us to evaluate whether the effect of oil wealth on economic growth differs between countries with different values of institutional quality. In this framework, $\rho$ in Equation (2) indicates the responsiveness of the steady state level of economic growth to oil wealth. Specifically, by differentiating Equation (1) with respect to oil wealth, we derive the marginal effect of oil wealth on economic growth as follows:

$$
\rho=\frac{\partial L G D P C}{\partial O L W}=\beta_{0}+\beta_{1} I N S Q .
$$

The contingency hypotheses in this specification centre around the coefficients $\beta_{0}$ and $\beta_{1}$, with the following four possibilities:

(a) If $\beta_{0}>0$ and $\beta_{1}>0$, oil wealth affects economic growth positively and institutional factors enhance that positive effect.

(b) If $\beta_{0}>0$ and $\beta_{1}<0$, oil wealth affects economic growth positively and institutional factors have a negative impact on this positive effect (institutional factors lessen this positive effect).

(c) If $\beta_{0}<0$ and $\beta_{1}>0$, oil wealth affects economic growth negatively and institutional factors mitigate this negative effect.

(d) If $\beta_{0}<0$ and $\beta_{1}<0$, oil wealth affects economic growth negatively and institutional factors exacerbate this negative effect.

From Equation (2), we can derive the threshold level of institutional quality beyond which oil wealth could enhance economic growth. From the equation, the positive effect of oil wealth on economic growth is found when the following conditions are satisfied:

$$
\rho>0 \leftrightarrow \quad \beta_{0}+\beta_{1} I N S Q>0 .
$$

Hence, the threshold level of institutional quality beyond which oil wealth would enhance economic is attained when INSQ $>\frac{-\beta_{0}}{\beta_{1}}$.

For model estimation, a panel autoregressive distributed lag (ARDL) estimation technique developed by Pesaran, Shin, and Smith [43] was utilized. This method is favoured by econometricians over other cointegration techniques because of its several merits, that is, it enables simultaneous estimation of both long-run and short-run parameters; it is applicable whether the regressors are purely $\mathrm{I}(0)$, purely I(1), or a combination of both; it avoids the problem of endogeneity; and it produces better results with small samples. To this end, the panel ARDL representation of Equation (1) is formulated as follows:

$$
\begin{aligned}
\triangle L G D P C_{i t}=\alpha_{0 i} & +\sum_{i=1}^{j} \beta_{1 i} \Delta L G D P C_{i, t-i}+\sum_{i=0}^{k} \beta_{2 i} \Delta O L W_{i, t-i} \\
& +\sum_{i=0}^{l} \beta_{3 i} \Delta\left(\operatorname{OLW}_{i, t-i} * I N S Q_{i, t-i}\right) \\
& +\sum_{i=0}^{m} \beta_{4 i} \Delta I N S Q_{i, t-i}+\sum_{i=0}^{n} \beta_{5 i} \Delta L Z_{i, t-i}+\theta_{1 i} L G D P C_{i, t-1}+\theta_{2 i} O L W_{i, t-1} \\
& +\theta_{3 i}\left(\operatorname{OLW}_{i, t-1} * I N S Q_{i, t-1}\right)+\theta_{4 i} I N S Q_{i, t-1}+\theta_{5 i} L Z_{i, t-1}+\varepsilon_{i t}
\end{aligned}
$$

where all variables are as defined earlier; $j, k, l, m$, and $n$ are lag orders; $\theta\left(\theta_{1 i}, \theta_{2 i}, \theta_{3 i}, \theta_{4 i}, \theta_{5 i}\right)$ is a vector of long-run parameters to be estimated; $\beta\left(\beta_{1 i}, \beta_{2 i}, \beta_{3 i}, \beta_{4 i}, \beta_{5 i}\right)$ is a vector of short-run parameters to be estimated, and $\varepsilon_{i t}$ is the error term.

Furthermore, in a bid to assess the robustness of our results, two additional estimations were carried out. First, another panel ARDL was conducted on Equation (3) with effective governance, from 
World Governance Indicators (WGI) of the World Bank as the proxy for institutional quality. Second, a two-step system generalized method of moments (GMM), suggested by Blundell and Bond [44], was employed to estimate the data used for the first panel ARDL regression. This method is also appropriate for this study, considering its ability to deal with the problem of endogeneity, which has been found to largely characterize institution variables [45-49]. To enable estimation by means of dynamic panel GMM, a dynamic panel model is formulated from Equation (1) as follows:

$$
L G D P C_{i t}=\varnothing_{i}+\alpha L G D P C_{i, t-1}+\beta_{0} O L W_{i t}+\beta_{1}\left(O L W_{i t} * I N S Q_{i t}\right)+\cap I N S Q_{i t}+\vartheta L Z_{i t}+\pi_{i}+\varepsilon_{i t},
$$

where $L G D P C_{i, t-1}$ and $\pi_{i}$ are lagged dependent variable and country-specific effect, respectively; and with other variables as defined earlier. To overcome the limitations of the differenced GMM introduced earlier by Arellano and Bond [50], the system GMM was introduced by Blundell and Bond [44], who suggested the use of moment conditions that combine both the first difference and the level equations, with the lagged levels of the regressors serving as the instruments for the level equations. Further, they posit that the validity of the instruments is predicated on the assumption that the correlation between the country-specific effect and the levels of the explanatory variables is constant over time. This assumption ensures that the country-specific effect and the first differences of the explanatory variables are uncorrelated. Thus, if $X$ represents a matrix of explanatory variables in Equation (4), the following moment conditions are applied for our model:

$$
\begin{gathered}
E\left[X_{i, t-s}, \Delta \varepsilon_{i t}\right]=0 \text { for } s \geq 2 ; t=3, \ldots, T, \\
E\left[\Delta X_{i, t-s,}\left(\varepsilon_{i t}+\pi_{i}\right)\right]=0 \text { for } s=1, t=3, \ldots, T .
\end{gathered}
$$

Thus, the system GMM encapsulates two regressions: one in differences and the other in levels. While the moment conditions in Equation (5) apply to the regression in differences, those in Equation (6) apply to the regression in levels. The system GMM is of two variants: one-step system GMM and two-step system GMM. We employed the two-step variant for this study's robustness test because it is more efficient than its one-step counterpart, as it uses optimal weighting matrices, which enables it to yield more efficient and consistent parameter estimates.

The consistency of the GMM estimator is dependent on two important specification tests, namely the Sargan test of over-identifying restrictions and the Arrelano and Bond [50] test of serial correlation (AR2). Failure to reject the null of the former indicates the validity of the instruments, while failure to reject the null of the latter indicates the absence of second-order serial correlation.

\subsection{Data}

Sets of annual data, covering a sample of 35 oil-exporting developing countries for the period 1984 to 2016, were utilized. The list of the countries is contained in the Appendix A. Data on oil wealth, represented by oil rent as a percentage of GDP, were sourced from the World Bank's World Development Indicators (WDI) [51]. It is defined as the value of crude oil production at international prices minus the total costs of production. Data on GDP per capita, representing economic growth, were also sourced from WDI [51]. For institutional quality, a composite index was constructed from the International Country Risk Guide (ICRG) institutional quality variables, sourced from the Political Risk Services (PRS) Group. The index was obtained by adding the following five institutional quality elements: (a) bureaucratic quality (range: $0-4$ ), which measures autonomy from political pressure and capability to govern without drastic changes in policy or interruptions in government services, as well as the existence of an established mechanism for recruitment and training of bureaucrats; (b) corruption (range: 0-6), which measures abuse of office for personal gains (countries with high levels of corruption have low index values and vice versa); (c) law and order (range: 0-6), which measures the strength, independence, and impartiality of the legal system, as well as the popular observance of the law; (d) democratic accountability (range: 0-6), which assesses the responsiveness of a government to its 
people; and (e) government stability (range: 0-12), which assesses a government's ability to execute its announced programmes and to stay in office. For the purpose of comparability, all sub-indicators of the index are standardized to range between 0 and 10, with higher values implying higher institutional quality and vice versa. Two control variables are included in the regression: investment (represented by gross fixed capital formation) and trade openness. Datasets on both control variables were sourced from WDI [51].

\section{Estimation and Results}

\subsection{Descriptive Statistics}

The descriptive statistics of the variables in the model are presented in Table 1 . The number of observations for each series is 1155 , obtained by multiplying the number of countries (35) by the number of years (33). On the average, oil wealth constitutes $14.1 \%$ of GDP of the oil-exporting developing countries over the study period, while it could be observed that the average level of institutional quality of the sampled countries is 5.1 out of 10 . Moreover, the variance is quite large for the entire series, as indicated by the substantial differences between the maximum and the minimum values of the variables. This is further underpinned by the standard deviation statistic for each variable, indicating a case of possible heterogeneity among the countries in the sample.

Table 1. Descriptive statistics.

\begin{tabular}{cccccc}
\hline Variable & GDPC & OLW & INSQ & INV & TRD \\
\hline Mean & $1.02 \times 10^{10}$ & 14.05104 & 5.052107 & 20.55726 & 69.54386 \\
Std. Dev. & $5.46 \times 10^{10}$ & 14.09499 & 1.03619 & 7.536911 & 36.56795 \\
Min & 432.3861 & 0.0483315 & 1.402778 & 1.369524 & 0.0209992 \\
Max & $4.56 \times 10^{11}$ & 64.013 & 7.763889 & 57.70911 & 220.4074 \\
Obs & 1155 & 1155 & 1155 & 1155 & 1155 \\
\hline
\end{tabular}

Source: Compiled by the authors.

\subsection{Panel Unit Root Tests}

Even though the ARDL cointegration procedure is applicable whether all the variables are integrated of order zero, or of order one, or of both orders, unit root tests still need to be undertaken to be sure that no I(2) variable is involved. The results of the Levin, Lin, and Chu (LLC); Im, Pesaran, and Shin (IPS); and Breitung panel unit root tests conducted on the series are presented in Table 2. An individual intercept was included in the test equation for each of the unit root tests, while the lag length for each variable was automatically selected by the Schwarz information criterion (SIC). As reported in the table, the integration properties of the variables hover around I(0) and I(1). The LLC test reports that only GDP per capita is integrated of order one and that the remaining five variables are integrated of order zero. On the other hand, IPS and Breitung tests report that GDP per capita and investment are integrated of order one, while the remainder of the series are integrated of order zero. We can, therefore, conclude that the variables in our model are integrated of orders zero and one, thereby reinforcing our choice of panel ARDL for model estimation. 
Table 2. Panel unit root test results. LLC—Levin, Lin, and Chu; IPS—Im, Pesaran, and Shin.

\begin{tabular}{|c|c|c|c|c|c|c|}
\hline \multirow{2}{*}{ Variable } & \multicolumn{2}{|l|}{ Level } & \multicolumn{4}{|c|}{ First Difference } \\
\hline & LLC & IPS & Breitung & LLC & IPS & Breitung \\
\hline LGDPC & -3.722 & -0.5888 & 8.8438 & $19.3691^{* * *}$ & $4.6989 * * *$ & $11.2507^{* * *}$ \\
\hline OLW & $11.4125^{* * *}$ & $2.3064^{* *}$ & $-5.0158^{* * *}$ & $32.0693 * * *$ & $6.6183^{* * *}$ & $22.7296^{* * *}$ \\
\hline INSQ & $10.3483^{* * *}$ & $2.0029 * *$ & $-1.9179 * * *$ & $26.2932^{* * *}$ & $5.5218 * * *$ & $-9.871 * * *$ \\
\hline$O L W * I N S Q$ & $11.3535^{* *}$ & $2.281 * * *$ & $-5.0563^{* * *}$ & $31.5992 * * *$ & $6.6973^{* * *}$ & $21.2659^{* * *}$ \\
\hline LINV & $10.9627 * * *$ & -1.9939 & -3.1378 & $26.7227^{* * *}$ & $5.3924^{* * *}$ & -15.6298 \\
\hline LTRD & $11.1084^{* * *}$ & -1.9693 & $-2.2262 * * *$ & $25.0645^{* * *}$ & $-5.694^{* * *}$ & $16.3238^{* * *}$ \\
\hline
\end{tabular}

\subsection{Hausman Test}

The panel ARDL estimation technique affords the opportunity to carry out model estimation with pooled mean group (PMG), mean group (MG), and dynamic fixed effect (DFE) estimators, each of which operates under different assumptions. It is, therefore, imperative to carry out the Hausman test in order to determine which of the three is most efficient for the analysis. The result of the Hausman test is presented in Table 3. Comparing MG with PMG using the test, we can observe from the table that the null hypothesis - that the PMG is more efficient-cannot be rejected, going by the insignificance of the chi-square coefficient. This implies that PMG is preferable to MG. However, comparing DFE with PMG, it is found that the null hypothesis-that PMG is more efficient than DFE-is rejected because of the significance of the chi-square coefficient, as indicated in Table 3. Hence, the DFE is adjudged as the most efficient of the three estimators, and is thus adopted for the model estimation.

Table 3. Hausman test. MG—-mean group; PMG—-pooled mean group; DFE—dynamic fixed effect.

\begin{tabular}{|c|c|c|}
\hline \multirow[b]{2}{*}{ MG vs. PMG } & \multicolumn{2}{|c|}{ Chi-Square Prob. } \\
\hline & 0.01582 & 1.0000 \\
\hline DFE vs. PMG & 1.63715 & $0.0000^{* * *}$ \\
\hline
\end{tabular}

\subsection{Panel ARDL Estimation}

The result of the panel ARDL with DFE estimation on the effect of institutions on the relationship between oil wealth and economic growth is reported in Table 4 . The report indicates that in the long run, the coefficient of oil wealth is significant and negative at a $1 \%$ significance level, indicating a negative impact of oil wealth on economic growth. Specifically, ceteris paribus, a 1\% increase in oil wealth would lead to a reduction in economic growth by $2 \%$, and vive-versa. The coefficient of the interaction variable $(O L W * I N S Q)$ is significant and positive at the $5 \%$ level. This result implies that while an increase in oil wealth depresses growth, this negative effect is mitigated in the countries with good institutions. Furthermore, the result indicates that in order for oil wealth to enhance economic growth in the long run, oil-exporting developing countries must achieve a level of institutional quality that is greater than the threshold level of $6.1(0.020341 / 0.003345=6.1)$. This indicates that oil wealth has a negative effect on economic growth in the sampled countries because of the low level of institutional quality in most of the countries, as the average value of institutional quality in the sampled countries is 5.05 (Table 1), which is lower than the 6.1 threshold value, derived in the estimation. This result corroborates that of Sarmidi et al. [26], who concluded that natural resources can enhance growth only after a certain threshold of institutional quality has been reached. The result also shows that institutional quality has a positive effect on economic growth in the sampled countries over the long run at the $5 \%$ level. Specifically, an increase of $1 \%$ in institutional quality would result in enhanced economic growth by about $0.08 \%$, ceteris paribus. This result corroborates Acemoglu et al. [52], Borrmann et al. [49], and Lee and Kim [53], who suggest that high quality institutions are very central 
to the realization of long-term economic growth across the world. However, the investment and trade openness variables are insignificant, which indicates that they do not affect the economic growth of the sampled countries in the long run.

Table 4. Panel autoregressive distributed lag (ARDL) results.

\begin{tabular}{|c|c|c|c|c|}
\hline Variable & Coefficient & Std. Error & z-Stat & Prob. \\
\hline \multicolumn{5}{|l|}{ Long run: } \\
\hline OLW & -0.020341 & 0.002108 & -9.65 & $0.00^{* * *}$ \\
\hline$O L W * I N S Q$ & 0.003345 & 0.001520 & 2.20 & $0.03^{* *}$ \\
\hline INSQ & 0.000775 & 0.000309 & 2.51 & $0.01^{* *}$ \\
\hline LINV & -0.054019 & 0.234468 & -0.23 & 0.82 \\
\hline LTRD & -0.064836 & 0.162090 & -0.40 & 0.69 \\
\hline \multicolumn{5}{|l|}{ Short run: } \\
\hline $\mathrm{D}(\mathrm{OLW})$ & 0.009647 & 0.001153 & 8.37 & $0.00 * * *$ \\
\hline $\mathrm{D}(\mathrm{OLW} * \mathrm{INSQ})$ & 0.002297 & 0.000621 & 3.70 & $0.00^{* * *}$ \\
\hline $\mathrm{D}(\mathrm{INSQ})$ & 0.042746 & 0.009354 & 4.57 & $0.00^{* * *}$ \\
\hline D(LINV) & 0.066106 & 0.021497 & 3.08 & $0.00^{* * *}$ \\
\hline D(LTRD) & 0.011339 & 0.014716 & 0.77 & 0.44 \\
\hline $\mathrm{ECT}_{\mathrm{t}-1}$ & -0.624113 & 0.012796 & -4.88 & $0.00 * * *$ \\
\hline
\end{tabular}

Turning to the short-run results, also in Table 4, the report shows that as opposed to the case in the long run, both oil wealth and the interaction variable have positive and significant coefficients, both at a $1 \%$ significance level. This implies that an increase in oil wealth enhances the economic growth of the sampled countries in the short run, and this positive impact is reinforced by institutional quality in countries with good institutions. Additionally, the estimation results show that in order for oil wealth to enhance economic growth in the short run, oil-exporting developing countries need to achieve a level of institutional quality that is greater than the threshold value of $4.2(0.009647 / 0.002297=4.2)$. This threshold result shows that oil wealth affects the economic growth of the sampled countries positively in the short run because of the presence of an adequate level of institutional quality in the short run, as the average level of institutional quality for the countries is 5.05 (Table 1); this is higher than the required threshold for the short run. As in the case with the long run result, institutional quality is reported in the table to also have a positive effect on economic growth in the short run at the $1 \%$ level. However, the investment variable, which turns out to be insignificant in the long run, has a significant and positive coefficient in the short run at a $1 \%$ level of significance. This indicates that an increase in investment enhances the economic growth of the sampled countries in the short run. Meanwhile, trade openness still remains insignificant in the short run, implying that it does not affect the economic growth of the sampled countries whether in the short run or in the long run.

Another important result in Table 4 is that of the error correction term (ECT), which is expected to be significant, negative, and less than unity for the variables to be adjudged as cointegrated. This condition is satisfied in the model as indicated in the table, and thus suggests that a long-run relationship exists among all the variables in the model. Furthermore, it indicates that adjustment from the short-run to the long-run equilibrium path is at the speed of $62 \%$.

\section{Robustness Check}

In order to test for the robustness of our results, two different estimations were carried out. First, another panel ARDL regression was performed with an alternative measure of institutional quality, namely effective governance (range: -2.5 to 2.5), sourced from World Governance Indicators [46] of the Word Bank. The estimation covers the period 1996 to 2017. The Hausman test conducted favours the adoption of the pooled mean group (PMG) estimator. From the estimation result presented in Table 5, the coefficient of oil wealth variable is negative and significant at a $1 \%$ significance level, in the long 
run, while that of the interaction variable is positive and significant at the $5 \%$ level. This indicates that institutional quality mitigates the negative effect of oil wealth on economic growth in the sampled countries in the long run. Moreover, the institutional quality threshold is estimated to be 1.84, which represents a minimum level of effective governance that sampled countries must achieve for oil wealth to impact economic growth positively. A similar result is also derived for the short run, where the threshold of institutional quality is found to be 1.78. While the coefficients of effective governance and investment are found to be significant and positive in both the long run and short run, indicating their positive impact on economic growth, the coefficient of trade openness is found to be significant and negative only in the long run, while it is insignificant in the short run. This implies that trade openness affects economic growth negatively in the long run, but has no short run effect on economic growth. The error correction term is also negative, less than unity, and significant, signifying the existence of a long-run relationship and the fact that previous deviation from equilibrium would be corrected in the current period. These results indicate that the findings in this study are consistent, irrespective of whether the institutional quality is measured by the ICRG variables or the WGI variable.

Table 5. Panel ARDL with World Governance Indicators (WGI) variables.

\begin{tabular}{|c|c|c|c|c|}
\hline Variable & Coefficient & Std. Error & z-Stat & Prob. \\
\hline \multicolumn{5}{|l|}{ Long run: } \\
\hline OLW & -0.068438 & 0.019179 & -3.57 & $0.00^{* * *}$ \\
\hline $\mathrm{OLW} * \mathrm{GOV}$ & 0.037190 & 0.014940 & 2.49 & $0.01^{* *}$ \\
\hline GOV & 0.062155 & 0.024471 & 2.54 & $0.04^{* *}$ \\
\hline LINV & 0.069589 & 0.012456 & 5.59 & $0.00^{* * *}$ \\
\hline LTRD & -0.052969 & 0.018697 & -2.83 & $0.00^{* * *}$ \\
\hline \multicolumn{5}{|l|}{ Short run: } \\
\hline $\mathrm{D}(\mathrm{OLW})$ & -0.003727 & 0.001762 & -2.12 & $0.03^{* *}$ \\
\hline $\mathrm{D}(\mathrm{OLW} * \mathrm{GOV})$ & 0.002094 & 0.000700 & 2.99 & $0.00^{* * *}$ \\
\hline $\mathrm{D}(\mathrm{GOV})$ & 0.000580 & 0.000200 & 2.90 & $0.00^{* * *}$ \\
\hline $\mathrm{D}(\mathrm{LINV})$ & 0.006046 & 0.001417 & 4.27 & $0.00^{* * *}$ \\
\hline D(LTRD) & -0.007486 & 0.004752 & -1.58 & 0.15 \\
\hline $\mathrm{ECT}_{\mathrm{t}-1}$ & -0.012168 & 0.004499 & -2.70 & $0.00^{* * *}$ \\
\hline \multicolumn{5}{|l|}{ Hausman test: } \\
\hline MG vs. PMG (Chi-Sq.) & 0.48 & & & 0.98 \\
\hline DFE vs. PMG (Chi-Sq.) & 0.86 & & & 1.00 \\
\hline
\end{tabular}

Second, an alternative estimation was carried out, using a two-step system generalized method of moments (GMM) estimator, suggested by Blundell and Bond [44], using the dataset used for the main regression, covering the period 1984-2016. In order to validate our use of the dynamic panel GMM estimator, which requires a large number of cross sections $(\mathrm{N})$ with a small number of time periods (T), the datasets were averaged into five-year intervals, with the last observation covering a three-year period (1984-1988, 1989-1993, 1994-1998, 1999-2003, 2004-2008, 2009-2013, and 2014-2016). This translates into seven observations for each country, thereby giving us $\mathrm{N}=35$ and $\mathrm{T}=7$ data dimension. The result of the GMM estimation is presented in Table 6. To verify the consistency of our GMM estimator, two specification tests were conducted, namely the Sargan test for over-identifying restriction and the Arellano-Bond (AR(2)) test for autocorrelation in the disturbances [48]. While the former tests the overall validity of the instruments employed, the latter tests the null hypothesis that the model does not suffer from second-order serial correlation. Given the statistical insignificance of the Hansen J-statistic, as shown in the table, we cannot reject the null hypothesis that our instruments are valid. Furthermore, the null hypothesis that the residuals do not suffer from second-order autocorrelation cannot be rejected, based on the insignificance of the $\mathrm{AR}(2)$ test. The results from the GMM estimation, as shown in the table, suggest that economic growth 
level tends to be influenced positively by its previous level, going by the significance and positive sign of the lagged dependent variable. Furthermore, the coefficient of oil wealth variable is found to be negative and significant, with the interaction variable also having a positive and significant coefficient, both at the $5 \%$ level. This indicates that institutional quality mitigates the negative effect of oil wealth on economic growth in countries with good institutions, with the institutional quality threshold estimated to be 5.40. This threshold represents the minimum level of institutional quality that the sample countries must attain for oil wealth to have a positive impact on economic growth. Institutional quality, investment, and trade openness variables are also shown to have positive and significant coefficients at $1 \%$ levels of significance, indicating their positive influence on economic growth in the sampled countries.

Table 6. Two-step system generalized method of moments (GMM) results.

\begin{tabular}{|c|c|c|c|c|}
\hline \multicolumn{5}{|c|}{ (N = 35 Countries; $T=7$; Sample Period: 1984-2016, Five-Year Average) } \\
\hline Variable & Coefficient & Std. Error & t-Stat & Prob. \\
\hline$L G D P C_{t-1}$ & 0.907291 & 0.005057 & 179.42 & $0.0000^{* * *}$ \\
\hline OLW & -0.001302 & 0.000611 & -2.13 & $0.0333^{* *}$ \\
\hline$O L W * I N S Q$ & 0.000241 & 0.000095 & 2.54 & $0.0270 * *$ \\
\hline INSQ & 0.019994 & 0.002661 & 7.51 & $0.0000^{* * *}$ \\
\hline$I N \widetilde{V}$ & 0.001530 & 0.000096 & 15.94 & $0.0000^{* * *}$ \\
\hline$T R D$ & 0.000081 & 0.000027 & 3.01 & $0.0027^{* *}$ \\
\hline \multicolumn{5}{|l|}{ Diagnostics: } \\
\hline Hansen J-test & & & & 0.418 \\
\hline$A R(1)$ & & & & 0.062 \\
\hline$A R(2)$ & & & & 0.317 \\
\hline
\end{tabular}

Overall, the results of Tables 5 and 6 are consistent with that of Table 4, thereby confirming that our results are robust to the alternative measure of institutional quality and the dynamic panel GMM estimation.

\section{Conclusions}

The relationship between natural resources and economic growth has long remained a subject of debate in the literature. Hence, this study was aimed at examining the impact of oil wealth on economic growth vis-à-vis the role of institutional quality in oil-exporting developing countries for sustainable development. To this end, a panel ARDL with a dynamic fixed effect estimator was applied for a sample of 35 countries covering the period 1984-2016. By employing a model with a linear interaction between oil wealth and institutional quality index, a contingent effect of oil wealth on economic growth, both in the long run and in the short run, was established. Specifically, institutional quality has been found to mitigate the negative effect of oil wealth on economic growth in the long run, while in the short run, institutional quality has been established to enhance the positive effect of oil wealth on economic growth. Furthermore, the institutional quality threshold levels beyond which oil wealth enhances economic growth are found to be 6.1 and 4.2 for the long run and short run, respectively.

These results have policy implications. Firstly, in order for improvement in oil revenue to be of benefit in galvanizing the economic growth of oil-exporting developing countries, oil exploration, production, sales, and the entire process in the oil wealth-generating chain in these countries must be embedded in a sound institutional framework. Secondly, oil-exporting developing countries should adopt appropriate policy measures to improve their levels of bureaucratic quality, law and order, and democratic accountability, as well as to reduce corruption, because findings from this study affirm that sound institutions are very important to the sampled countries, to enable the gains from oil revenue to translate into growth for the various economies under consideration. In conclusion, wealth from 
natural resources has, in some developing countries, led to the phenomenon of the "resource curse". The resource needs to be utilized in a sustainable way to benefit all members of the population and not to create negative environmental impacts, leading to degradation of the environment and eventually a loss of the resource. This can be achieved through environmental protection legislations by the appropriate governmental authorities. For example, in Nigeria, efforts have been on for several years to pass the petroleum industry bill into law, which, in addition to enhancing the institutional and governance structure of the industry to stimulate investment, is also aimed at reducing the negative environmental impacts of the industry on the populace, such as the stoppage of the highly hazardous gas flaring, which is still being practiced in oil drilling by the oil companies. Furthermore, corporate social responsibilities, geared towards ameliorating any negative environmental impacts arising from crude oil production should be improved upon by oil-producing firms in order to enhance the welfare of the populace, protect the environment, and engender sustainable development.

Author Contributions: Conceptualization, A.S.H. and D.F.M.; methodology, A.S.H. and D.F.M.; software, validation, A.S.H. and D.F.M.; formal analysis, D.F.M.; investigation, A.S.H., D.F.M.; resources, D.F.M., A.S.H.; data curation, A.S.H. and D.F.M.; writing-original draft preparation, A.S.H. and D.F.M.; writing-review and editing, D.F.M. and S.K.; visualization, A.S.H. and D.F.M.; supervision, D.F.M; project administration, D.F.M.; funding acquisition, S.K.

Funding: No external funding was used in the development of this paper.

Conflicts of Interest: The authors declare no conflict of interest.

\section{Appendix A}

Table A1. List of countries.

\begin{tabular}{ccccc}
\hline Albania & Brunei & Gabon & Malaysia & Sudan \\
Algeria & Cameroon & Indonesia & Mexico & Syria \\
Angola & Colombia & Iran & Nigeria & Thailand \\
Argentina & Cote d'Ivoire & Iraq & Oman & Trinidad and Tobago \\
Azerbaijan & Cuba & Kazakhstan & Peru & Tunisia \\
Bahrain & Ecuador & Kuwait & Qatar & Venezuela \\
Brazil & Egypt & Libya & Saudi Arabia & Yemen \\
\hline
\end{tabular}

\section{References}

1. Sachs, J.D.; Warner, A.M. Fundamental sources of long-run growth. Am. Econ. Rev. 1997, 87, 184-188.

2. Gylfason, T. Natural Resources and Economic Growth: From Dependence to Diversification; CEPR Discussion Paper No. 4804; CEPR: Washington, DC, USA, 2004; Available online: https://ssrn.com/abstract=697881 (accessed on 15 March 2019).

3. Mehlum, H.; Moene, K.; Torvik, R. Institutions and the resource curse. Econ. J. 2006, 116, 1-20. [CrossRef]

4. Bhana, N. Corporate social responsibility initiatives and its impact on firm share price performance: Evidence from South Africa. J. Contemp. Manag. 2018, 15, 100-126.

5. Sachs, J.D.; Warner, A.M. Natural Resource Abundance and Economic Growth; NBER Working Paper, No. 5398; NBER: Cambridge, MA, USA, 1995.

6. Auty, R.M. Resource Abundance and Economic Development; Oxford University Press: Oxford, UK, 2001.

7. Gylfason, T. Natural resources, education and economic development. Eur. Econ. Rev. 2001, 45, 847-859. [CrossRef]

8. Ross, M.L. The politics of the resource curse: A review. In Handbook on the Politics of Development; Lancaster, C., van de Walle, N., Eds.; Oxford University Press: Oxford, UK, 2013.

9. Gylfason, T.; Zoega, G. Inequality and Economic Growth: Do Natural Resources Matter? CESifo Working Paper Series 712; CESifo Group: Munich, Germany, 2002.

10. Frankel, J. The Natural Resource Curse: A Survey; NBER Working Paper No. 15836; NBER: Cambridge, MA, USA, 2010.

11. Świerczyńska, K. Structural transformation and economic development in the best performing sub-Saharan African states. Equilib. Q. J. Econ. Econ. Policy 2017, 12, 547-571. [CrossRef] 
12. Rajiani, I.; Bačík, R.; Fedorko, R.; Rigelský, M.; Szczepańska-Woszczyna, K. The alternative model for quality evaluation of health care facilities based on outputs of management processes. Pol. J. Manag. Stud. 2018, 17, 194-208. [CrossRef]

13. Collier, P.; Hoeffler, A. Greed and Grievance in Civil War; World Bank Policy Research Paper 2355; The World Bank: Washington, DC, USA, 2000.

14. African Development Bank. The African Economic Outlook; African Development Bank: Abidjan, Cote d'Ivoire, 2018.

15. Larsen, E.R. Escaping the resource curse and the Dutch disease? When and why Norway caught up with and forged ahead of its neighbours. Am. J. Econ. Sociol. 2006, 65, 605-640. [CrossRef]

16. Kuc, M. Social convergence in Nordic countries at regional level. Equilib. Q. J. Econ. Econ. Policy 2017, 12, 25-41. [CrossRef]

17. Brunnschweiler, C.N. Cursing the blessings? Natural resource abundance, institutions and economic growth. World Dev. 2008, 36, 399-419. [CrossRef]

18. Brunnschweiler, C.N.; Bulte, E.H. Natural resources and violent conflict: Resource abundance, dependence and the onset of civil wars. Oxf. Econ. Pap. 2009, 61, 651-674. [CrossRef]

19. Boyce, J.R.; Emery, J.C. Is a negative correlation between resource abundance and growth sufficient evidence that there is a "resource curse"? Resour. Policy 2010, 36, 1-13. [CrossRef]

20. Popp, J.; Kot, S.; Lakner, Z.; Oláh, J. Biofuel use: Peculiarities and implications. J. Secur. Sustain. Issues 2018, 7, 477-493. [CrossRef]

21. Popp, J.; Oláh, J.; Farkas Fekete, M.; Lakner, Z.; Máté, D. The relationship between prices of various metals, oil and scarcity. Energies 2018, 11, 2392. [CrossRef]

22. Kurowska-Pysz, J. Assessment of trends for the development of cross-border cultural clusters at an example of Euroregion Cieszyn Silesia. Forum Sci. Oeconomia 2015, 1, 31-51.

23. Damania, R.; Bulte, E. Resource for Sale: Corruption, Democracy and the Natural Resource Curse; Discussion Paper No. 0320; Center for International Studies, University of Adelaide: Adelaide, Australia, 2003.

24. Shuaibu, M.; Oladayo, P.T. Determinants of human capital development in Africa: A panel data analysis. Oeconomia Copernic. 2016, 7, 523-549. [CrossRef]

25. Acemoglu, D.; Johnson, S.; Robinson, J.A. An African success: Botswana. In Analytic Development Narratives; Rodriquez, D., Ed.; Princeton University Press: Princeton, NJ, USA, 2002.

26. Sarmidi, T.; Law, S.H.; Jafari, Y. Resource curse: New evidence on the role of institutions. Int. Econ. J. 2014, 28, 191-206. [CrossRef]

27. Olomola, P.A. Oil Wealth and Economic Growth in Oil-Exporting African Countries; AERC Research Paper 170; African Economic Research Consortium: Nairobi, Kenya, 2007.

28. Olayungbo, D.O.; Adediran, K.A. Effects of oil revenue and institutional quality on economic growth with an ARDL approach. Energy Policy Res. 2017, 4, 44-54. [CrossRef]

29. Draskovic, M.; Bauk, S.; Delibasic, M. Testing the level and factors of institutional rationality in Montenegro, Serbia and Bosnia and Herzegovina. Econ. Sociol. 2016, 9, 27-45. [CrossRef]

30. Draskovic, M.; Milica, D.; Mladen, I.; Chigisheva, O. Preference of institutional changes in social and economic development. J. Int. Stud. 2017, 10, 318-328. [CrossRef]

31. Papyrakis, E.; Gerlagh, R. The resource curse and transmission channels. J. Comp. Econ. 2004, 32, 181-193. [CrossRef]

32. Torvik, R. Natural resources, rent seeking and welfare. J. Dev. Econ. 2002, 67, 455-470. [CrossRef]

33. Alexeev, M.; Conrad, R. The elusive curse of oil. Rev. Econ. Stat. 2009, 91, 586-598. [CrossRef]

34. Victor, P.; Vladimir, P.; Alexander, T. Resource Abundance: A Curse or Blessing; DESA Working Paper No. 93, ST/ESA/2010/DWP/93; DESA: New York, NY, USA, 2010.

35. Hansen, B.E. Sample Splitting and Threshold Estimation; Boston College Working Papers in Economics 319; Boston College Department of Economics: Boston, MA, USA, 1996.

36. Hansen, B.E. Sample splitting and threshold estimation. Econometrica 2000, 68, 575-604. [CrossRef]

37. Tsui, K.K. More oil, less democracy: Evidence from worldwide crude oil discoveries. Econ. J. 2010, 121, 89-115. [CrossRef]

38. Godwin, E.A.; Chuka, C. Natural resources, human capital and economic development in Nigeria: Tracing the linkages. J. Econ. Sustain. Dev. 2014, 5, 35-52. 
39. Leite, C.; Weidmann, J. Does mother nature corrupt? Natural resources, corruption and economic growth. In Governance, Corruption and Economic Performance; Abed, G., Gupta, S., Eds.; International Monetary Fund: Washington, DC, USA, 2002; pp. 156-169.

40. Smith, B. Oil wealth and regime survival in the developing world. Am. J. Political Sci. 2004, 48, $232-246$. [CrossRef]

41. Akinwale, Y.O. Empirical analysis of resource curse in Nigeria. Int. J. Econ. Manag. Sci. 2012, 1, 19-25.

42. Ologunla, S.E.; Kareem, R.O.; Raheem, K.A. Institutions and the resource curse in Nigeria. J. Sustain. Dev. Stud. 2014, 1, 36-51.

43. Pesaran, M.H.; Shin, Y.; Smith, R. Bounds testing approaches to the analysis of level relationships. J. Appl. Econom. 2001, 16, 289-326. [CrossRef]

44. Blundell, R.; Bond, S. Initial conditions and moment restrictions in dynamic panel data models. J. Econom. 1998, 87, 115-143. [CrossRef]

45. Acemoglu, D.; Johnson, S.; Tchaicharoen, Y. Institutional causes, macroeconomic symptoms: Volatility, crises and growth. J. Monet. Econ. 2003, 50, 49-123. [CrossRef]

46. Acemoglu, D.; Johnson, S.; Robinson, J.A. Institutions as a fundamental cause of long-run growth. In Handbook of Economic Growth; Aghion, P., Durlauf, S.N., Eds.; Elsevier: Amsterdam, The Netherlands, 2005; Volume 1A. [CrossRef]

47. Rodrik, D.; Subramanian, A.; Trebbi, F. Institutions rule: The primacy of institutions over geography and integration in economic development. J. Econ. Dev. 2004, 9, 131-165. [CrossRef]

48. Vitola, A.; Senfelde, M. The role of institutions in economic performance. Bus. Theory Pract. 2015, 16, $271-279$. [CrossRef]

49. Borrmann, A.; Busse, M.; Neuhaus, S. Institutional Quality and the Gains from Trade; Hamburgisches Welt-Wirtschafts-Archiv (HWWA), Hamburg Institute of International Economics: Hamburg, Germany, 2006.

50. Arellano, M.; Bond, S. Some tests of specification for panel data: Monte Carlo evidence and an application to employment equations. Rev. Econ. Stud. 1991, 58, 227-297. [CrossRef]

51. The World Bank. World Development Indicators; World Bank Database: Washington, DC, USA, 2018.

52. Acemoglu, D.; Johnson, S.; Robinson, J.A. Reversal of fortunes: Geography and institutions in the making of the modern world income distribution. Q. J. Econ. 2002, 117, 1231-1294. [CrossRef]

53. Lee, K.; Kim, B.Y. Both institutions and policies matter but differently for different income groups of countries: Determinants of long-run economic growth revisited. World Dev. 2009, 37, 533-549. [CrossRef] 